\title{
Management of energy efficient measures by buildings' thermorenovation
}

\author{
Jurgis Zemitis ${ }^{1}$, Maxim Terekh ${ }^{2 *}$ \\ ${ }^{1}$ Department of Heat and Gas technology, Riga Technical University, Riga, Latvia \\ ${ }^{2}$ Department of Construction of Unique Buildings and Structures, Peter the Great St. Petersburg \\ Polytechnic University, St. Petersburg, Russian Federation
}

\begin{abstract}
The system of integral indexes for estimation of economic efficiency of warm isolations of dwelling and civil buildings is resulted in the article. For the management by energysavings measures during realization of investment projects in the conditions of financial limitations effectively to apply economic-mathematical methods. Application of method of the dynamic programming at the choice of effective measures on the heatcover of barriering constructions of buildings allows to get the mixed optimum strategy of the use of the limited investments.
\end{abstract}

\section{Introduction}

Energy conservation is a pressing Problem for several decades in many countries of the world. A considerable share of energy consume homes and civic buildings due to the low heat-shielding properties of enclosing structures of buildings $[9,14,19]$. To increase the thermal resistance of frame structures is developed by a large number of constructive solutions using different materials. For the adoption of the optimal solution for the device additional insulation there are different methods of an estimation of economic efficiency of a constructive solution to the thermal insulation.

Now in world and domestic practice is widely used in competition form of realization of investment projects, particularly at the design stage. In the midst of a deep crisis in the country's economy and, consequently, the lack of budgetary funds, a very important task is to make the best use of them [18]. This goal can only be achieved with the implementation of investment projects on a competitive basis, provided the optimum use of allocated funds.

The solution of this problem is necessary while planning and carrying out various kinds of activities in implementation of investment projects in construction, including a complex of energy-saving activities in residential and civic buildings.

Statement of the problem. Insulation of protecting designs of the existing housing stock, resistance to heat does not meet current Thermo-technical norms, resulting in greater heat loss, and due to the high cost and scarcity of energy resources, is a pressing problem and the most important economic task.

At present, the assessment of the effectiveness of insulation for residential and civil buildings should be conducted on the basis of calculation of integral indicators of the

*Corresponding author: m_terekh@mail.ru 
project additional insulation. Along with the existence of normative values of resistance of enclosures, designing of enclosures can be carried out, defining the optimal values of resistance that will yield maximum net discounted revenue (NPV) during construction and operation of enclosures $[6,11]$. Also when addressing the challenges of reducing heat loss buildings and structures should take into account the whole range of energy saving measures: insulation not only walls, but the basement and Garret overlapping's, replacing old Windows with new high thermal resistance, reduce seepage losses [13].

The purpose of the study. To undertake energy efficiency measures will require substantial investments which are often limited. It is therefore very important to distribute available funds between fine-tuned so that the economic benefits from investment funds.

\section{Methods}

In the conditions of a planned economy criterion of efficiency of capital investments served at least listed costs [7]. To select an option use the recommended capital investment following formulas:

$$
\begin{aligned}
& \mathrm{P}_{\mathrm{i}}=\mathrm{K}_{\mathrm{i}}+\mathrm{T}_{\mathrm{n}} \cdot \mathrm{C}_{\mathrm{i}} \Rightarrow \min , \\
& \mathrm{P}_{\mathrm{i}}=\mathrm{C}_{\mathrm{i}}+\mathrm{E}_{\mathrm{n}} \cdot \mathrm{K}_{\mathrm{i}} \Rightarrow \min ,
\end{aligned}
$$

where $\mathrm{K}_{\mathrm{i}}$ - capital investment in the $\mathrm{i}$-th version;

$\mathrm{C}_{\mathrm{i}}$ - the cost price (current expenses) according to the $\mathrm{i}$-th version;

$\mathrm{T}_{\mathrm{n}}$ - the standard payback period for additional capital investments due to savings from lower current costs;

$E_{n}$ - the normative coefficient of efficiency of capital investments.

Economically optimal thermal resistance $\mathrm{R}^{\mathrm{ec}}{ }_{\mathrm{o}}$ of walling should be taken on the basis of providing the lowest cost given $\mathrm{p}$, defined by the calculation for frame structures with different heat transfer resistance $\mathrm{R}_{\mathrm{o}}$ :

$$
\mathrm{P}=\mathrm{C}_{\mathrm{d}}+\frac{\left(\mathrm{t}_{\text {int }}-\mathrm{t}_{\mathrm{ot}}\right) \cdot \mathrm{Z}_{\mathrm{ot}} \cdot \mathrm{m} \cdot \mathrm{C}_{\mathrm{T}} \cdot \mathrm{l}_{\mathrm{T}}}{\mathrm{R}_{\mathrm{o}} \cdot \mathrm{E}_{\mathrm{np}}},
$$

where $\mathrm{C}_{\mathrm{d}}$ - one-time costs (cost of construction and installation works), rub. $/ \mathrm{m}^{2}$;

Ro - thermal resistance of enclosing structures, taken for calculation options equal to and close to the value of heat transfer resistance, defined by the formula in [8].

Evaluation of the cost-effectiveness of additional thermal protection of protecting designs on the above methods is carried out without taking into account the time factor (discounting) and saving money on heating during the operation after the period of recoupment.

In the book [6] A.N. Dmitriyev technique of optimizing the level of thermal protection of protecting designs in which the optimality criterion provides maximum net profit from preserve of heat energy for EST. N fencing service with additional thermal insulation:

$$
\mathrm{S}(\mathrm{m})=\mathrm{P}(\mathrm{m}) \cdot \mathrm{N}-\mathrm{C}(\mathrm{m})
$$

where $S(m)$-net profit,

$\mathrm{P}(\mathrm{m})$-the cost of energy savings annually, 
$\mathrm{C}(\mathrm{m})$-the cost of the device is an additional layer of insulation,

$\mathrm{m}$ is the coefficient of increase of level of thermal protection of protecting designs.

However, this method does not take into account the change in the value of money over time.

In connection with the operation of the market comparison methodology effective technology and investment options for the cost does not reflect the real economic indicators. Currently, the evaluation of the effectiveness of insulation for residential and civil buildings should be conducted on the basis of calculations of economic indicators in view of the time factor, i.e. discounting $[3,4]$. The most common is integral indicators: NPV, additional capital investment yield index (ACIYI), internal rate of return (IRR), payback additional capital investments, which are based on the concept of discounting.

NPV indicator, which displays the values of growth as a result of project implementation, because it represents the difference between the amount of cash flows that arise during the project implementation and provides (discounted) to their present value, and the sum of the discounted values of all expenses necessary for the implementation of the project.

$$
\mathrm{NPV}=\sum_{t=0}^{T} \frac{\left(R_{t}-W_{t}\right)}{(1+r)^{t}}
$$

where $\mathrm{R}_{\mathrm{t}}$-results on $\mathrm{t}$-th step;

$\mathrm{W}_{\mathrm{t}}$-costs on $\mathrm{t}$-th step;

$\mathrm{T}$ - the duration of the calculation period;

$\mathrm{r}$-permanent rule discount equal to the acceptable norm of income investor capital.

For device projects an additional thermal protection of protecting designs, when investment is invested in the very beginning of the project, and cash (savings for heating) in each period are the same in magnitude, NPV formula takes the form:

$$
\mathrm{NPV}=\mathrm{E} \cdot \frac{1-(1+\mathrm{r})^{-\mathrm{T}}}{\mathrm{r}}-\mathrm{K}
$$

where $\mathrm{E}$ - the annual savings in heating money due to the increase in thermal resistance of the enclosing structures;

$\mathrm{K}$ - capital costs for the device of additional thermal insulation;

$\mathrm{T}$ - the duration of the billing period; $\mathrm{r}$ is a constant discount rate equal to the rate of return on capital acceptable for an investor.

$$
\mathrm{E}=\left(\mathrm{t}_{\text {int }}-\mathrm{t}_{\mathrm{ot}}\right) \cdot \mathrm{Z}_{\mathrm{ot}} \cdot \mathrm{m} \cdot \mathrm{l}_{\mathrm{T}} \cdot \mathrm{C}_{\mathrm{T}} \cdot\left(\frac{1}{\mathrm{R}_{\mathrm{o}}}-\frac{1}{\mathrm{R}}\right),
$$

where $\mathrm{R}, \mathrm{R}_{\mathrm{o}}$-thermal resistance of enclosures respectively before and after the device additional insulation.

$$
\mathrm{K}=\mathrm{C}_{\mathrm{k}}+\delta_{\mathrm{hi}} \cdot \mathrm{C}_{\mathrm{hi}}
$$

where $\mathrm{C}_{\mathrm{k}}$ - the cost of the building envelope without taking into account the cost of the thermal insulation layer (the cost of performing work on the device of additional thermal insulation plus the cost of materials of the protective and finishing layer). 
Dissemination of project performance evaluation method using NPV subject to directly define the effect of the project (its absolute value), as well as to assess the cumulative net income from several independent projects. However, the NPV does not display the relative measure of gain values as a result of the project, which also has substantial value for investors[7].

Project profitability index (ID)-an indicator that displays the ratio of the sum of the discounted cash flows to the sum of all costs that are discounted to the initial period. Additional insulation for the project formula for determining ID takes the form:

$$
\mathrm{ID}=\mathrm{E} \cdot \frac{1-(1+\mathrm{r})^{-\mathrm{T}}}{\mathrm{r}} / \mathrm{K}
$$

Disadvantages of index yields the following:

- It is not suitable for ranking on the benefits of independent projects and absolutely not suitable for selecting mutually exclusive projects;

- as compared to the relative size of revenues to expenses, it should be remembered that this figure does not show the actual amount of the net revenue from the project. So a small project can be much greater than a large project ID, and, if you do not use additional calculations of the indicator, you can accept the NPV erroneous decision on the project.

Internal rate of return (IRR) represents the norm discount $r$, where the value of the listed effects equals the given investment.

$$
\mathrm{E} \cdot \frac{1-\left(1+\mathrm{r}_{\text {in }}\right)^{-\mathrm{T}}}{\mathrm{r}_{\text {in }}}=\mathrm{K},
$$

IRR, you can define a method of successive approximations. IRR displays the boundary value of the discount rate, above which the project becomes unprofitable.

Payback period-the minimum time interval from the beginning of the project, beyond which the NPV becomes and remains non-negative. Payback period, we recommend that you define using the discounting.

$$
\mathrm{Tpb}=\frac{\ln \mathrm{E}-\ln (\mathrm{E}-\mathrm{K} \cdot \mathrm{r})}{\ln (1+\mathrm{r})},
$$

Payback period acts as the decisive factor, if

1. leadership is concerned about the decision of the liquidity problems, rather than the profitability of the project is the main thing that investment paid off, as soon as possible;

2. investments involve a high degree of risk (the shorter the payback period, the less risky the project).

\section{Results and Discussion}

Because the correlation between economic and thermotechnical characteristics of frame structures are not linear, then for the task we will use the method of dynamic programming $[1,2]$.

Dynamic programming is a special optimization method adapted to the so-called "multistep" operations.[8] Having a limited number of investments to interventions to reduce heat 
loss in buildings $\mathrm{m}_{1}, \mathrm{~m}_{2}, \ldots, \mathrm{m}_{\mathrm{n}}$, you want to determine the level of funding for each of them. The optimization criterion in this case can serve NPV, which takes into account both the costs of energy-saving measures and results of their implementation. Each of the activities mi when attaching to it a part of investment $\mathrm{x}$ brings NPV eventually. For each activity set features $\mathrm{NPV}_{\mathrm{i}}=\mathrm{ji}(\mathrm{x})(\mathrm{i}=1,2, \ldots, \mathrm{n})$. these functions should be not decreasing .

For illustrative purposes, consider the following example of a numerical example. It is necessary to carry out a set of measures to reduce heat loss by having a limited number of investments in the course of thermorenovation the following activities are envisaged:

- thermal insulation of external walls from the outside;

- thermal insulation of basement slab;

- Attic floor insulation;

- replacing old windows with new ones.

To solve the task, you must specify the dependency feature of NPV investments for each of the activities on termorenovation $[3,5]$.

Selecting the way of the device additional insulation (inner or outer), as well as insulating material, find the dependencies for each of NPV named events from investment to thermorenovation.

Having optimization, we obtain the final allocation of investment in thermorenovation.

Thus, the solution get mixed optimal strategy for use of limited investment.

It should be noted that the distribution of in the received NPV 2.1 times more than if all the funds spent on insulation of exterior walls, at 1.9 times more than if all the funds spent on replacement Windows, and in 1.2 anymore-if all funds spent equally on thermal insulation of walls and replacing Windows.

\section{Conclusion}

In the prevailing economic conditions, the main indicators of economic efficiency of projects, including projects on introduction of energy saving measures are indicators based on discounting.

Using the method of dynamic programming, you can solve an important task optimization for thermorenovation buildings and structures-most efficiently distribute the limited investment in each one and determine to what extent these energy-saving measures will be carried out with the aim of obtaining the maximum value of the NPV

\section{References}

1. E. Venttsel, Research of operations: tasks, principles, methodology, (M.: Science, Hl. physical edition. - a mat. liters, 1988)

2. E. Kudryavtsev, A research of operations in tasks, algorithms and programs, (M.: Radio and communication, 1984)

3. V. Kovalyov, Financial analysis: Management of the capital. Choice of investments. Analysis of the reporting, (2nd prod., reslave. and additional - M.: Finance and statistics, 1997)

4. V. Shapiro, Project management, (SPb.: Two-three, 1996)

5. V. Bogoslovskiy, V. Novozhilov, B. Simakov, V. Titov. Heating and ventilation: The textbook for higher education institutions, (the 2nd prod., reslave. and additional - M.: Stroyizdat, 1980) 
6. A. Dmitriyev, Management of energy saving innovations in construction of buildings, (Manual, M, DIA, 2000)

7. M. Pedan, Construction economy: Studies for higher education institutions, (M.: Stroyizdat, 1987)

8. S. Bayramukov, Z. Dolayeva, Mag. of Civ. Eng., 8, 3 (2017).

9. A. Borodinets, Y. Zemitis, Y. Sorokins, D. Baranov, Mag. Civ. Eng., 8, 58 (2016)

10.E. Statsenko, A. Ostrovaya, T. Musorina, M. Kukolev, M. Petrichenko, Mag. Civ. Eng., 8, 86 (2016)

11. M. Korovina, Constr. Un. Build. Struct., 11, 93 (2017)

12.D. Tseytin, N. Vatin, D. Nemova, P. Rymkevich, A. Gorshkov, Constr. Un. Build. Struct., 1, 20 (2016)

13. T. Musorina, O. Gamayunova, M. Petrichenko, MGSU Bulletin, 11, 1269 (2017)

14. A.S. Gorshkov, N.I. Vatin, P.P. Rymkevich, O.O. Kydrevich, Mag. Civ. Eng., 2, 65 (2018)

15. D. Zaborova, M. Kukolev, T. Mussorina, M. Petritchenko, Sci. Tech. Sheets SPbSTU, 4, 28 (2016)

16. E. Ivanova, A. Gorshkov, Constr. Un. Build. Struct., 4, 58 (2016)

17. A. Kopylova, A. Bogomolova., D. Nemova, Constr. Un. Build. Struct., 10, 20 (2016)

18. A. Gorshkov, N. Vatin, D. Nemova, A. Shabaldin, L. Melnikova, P. Kirill, Proc. Eng., 117, 1085 (2015)

19. A. Kiryudcheva, V. Shishkina, D. Nemova, Constr. Un. Build. Struct., 5, 19 (2016)

20. D. Sovetnikov, D. Semashkina, D. Baranova Constr. Un. Build. Struct., 12, 7 (2016)

21. R. Alihodzic, V. Murgul, N. Vatin, E. Aronova, V. Nikolić, M. Tanić, D. Stanković., Appl. Mech. Mater., 624, 604 (2014)

22. N. Vatin, D. Nemova, L. Khazieva, D. Chernik, Appl. Mech. Mater., 635-637, 2057 (2014)

23. M. Petrichenko, D. Nemova, E. Kotov, D. Tarasova, V. Sergeev, Mag. Civ. Eng., 77, 47 (2018)

24. M. Petrichenko, N. Vatin, D. Nemova, N. Kharkov, A. Korsun, Appl. Mech. Mater., 672-674, 1903 (2014)

25. N. Vatin, D. Nemova, A. Kazimirova, K. Gureev, Adv. Mater. Res., 953-954, 1537 (2014)

26. G. Grinfeld, A. Gorshkov, N. Vatin, Adv. Mater. Res., 941-944, 786 (2014) 